OPEN ACCESS

Edited by:

Zhichang Chen,

Fujian Agriculture and Forestry

University, China

Reviewed by:

Mian Gu,

Nanjing Agricultural University, China

Jiang Tian,

South China Agricultural University,

China

*Correspondence:

Xuexian $\mathrm{Li}$

steve@cau.edu.cn

Specialty section: This article was submitted to

Plant Abiotic Stress,

a section of the journal

Frontiers in Plant Science

Received: 11 December 2019

Accepted: 07 February 2020

Published: 28 February 2020

Citation:

Nadeem F, Ahmad Z,

UI Hassan M, Wang R, Diao X and

LiX (2020) Adaptation of Foxtail Millet (Setaria italica L.) to Abiotic Stresses: A Special Perspective of Responses

to Nitrogen and Phosphate

Limitations. Front. Plant Sci. 11:187.

doi: 10.3389/fpls.2020.00187

\section{Adaptation of Foxtail Millet (Setaria italica L.) to Abiotic Stresses: A Special Perspective of Responses to Nitrogen and Phosphate Limitations}

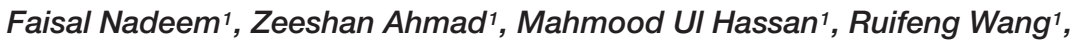 \\ Xianmin Diao $^{2}$ and Xuexian $L^{i^{1 *}}$
}

1 MOE Key Laboratory of Plant-Soil Interactions, Department of Plant Nutrition, China Agricultural University, Beijing, China,

${ }^{2}$ Institute of Crop Sciences, Chinese Academy of Agricultural Sciences, Beijing, China

Amongst various environmental constraints, abiotic stresses are increasing the risk of food insecurity worldwide by limiting crop production and disturbing the geographical distribution of food crops. Millets are known to possess unique features of resilience to adverse environments, especially infertile soil conditions, although the underlying mechanisms are yet to be determined. The small diploid genome, short stature, excellent seed production, $\mathrm{C}_{4}$ photosynthesis, and short life cycle of foxtail millet make it a very promising model crop for studying nutrient stress responses. Known to be a drought-tolerant crop, it responds to low nitrogen and low phosphate by respective reduction and enhancement of its root system. This special response is quite different from that shown by maize and some other cereals. In contrast to having a smaller root system under low nitrogen, foxtail millet enhances biomass accumulation, facilitating root thickening, presumably for nutrient translocation. The low phosphate response of foxtail millet links to the internal nitrogen status, which tends to act as a signal regulating the expression of nitrogen transporters and hence indicates its inherent connection with nitrogen nutrition. Altogether, the low nitrogen and low phosphate responses of foxtail millet can act as a basis to further determine the underlying molecular mechanisms. Here, we will highlight the abiotic stress responses of foxtail millet with a key note on its low nitrogen and low phosphate adaptive responses in comparison to other crops.

Keywords: foxtail millet, abiotic stresses, nitrogen limitation, phosphate starvation, transporter

\section{INTRODUCTION}

Abiotic and biotic environmental stresses reduce plant growth and yield below optimum levels. According to an FAO report released in 2007, only 3.5\% of the global area is not affected by environmental constraints, contributing to $50-70 \%$ of crop yield reduction (Boyer, 1982; Mittler, 2006). Being sessile in nature, plants encounter these environmental challenges while obtaining 
the carbon, water, and nutrients necessary for development, growth, and biomass production. The dynamic and complex responses of plants to abiotic stresses can be elastic (reversible) or plastic (irreversible) (Cramer, 2010; Skirycz and Inze, 2010). Plant growth is based on cell proliferation, which requires the persistent availability of nutrients, water, and energy; hence, plants survive through acclimatory responses to nutrient, water, light, and temperature fluctuations.

Roots are vital for optimum crop production because, as well as their water and nutrient uptake functionality, they provide anchorage of plants to soils, store essential elements, and have symbiotic relationships with microorganisms present in the rhizosphere (Bechtold and Field, 2018). Drought, soil salinity, and nutrient toxicity and deficiency are frequent stresses directly encountered by plant roots, leading them to modify or alter their growth as per environmental signaling. The geochemical processes of rock weathering replenish soils with nutrients, except for nitrogen, which originates primarily from atmospheric nitrogen $(\mathrm{N})$ fixation. The natural impoverishment of some nutrients leads to their deficiencies in soils. Nutrient limitation is a limiting factor in crop growth and production that originates from a combination of natural and anthropogenic processes (Sanchez and Salinas, 1981; Giehl and von Wirén, 2014).

$\mathrm{N}$ is an important macronutrient governing crop productivity through the regulation of growth and development. $\mathrm{N}$ exists in soils heterogeneously, either as inorganic forms, i.e., nitrate and ammonium, or organic forms, like amino acids, peptides, and lipids. Organic forms of nitrogen persist in specific habitats such as boreal and tropical ecosystems. Nitrate and ammonium are the predominant forms of $\mathrm{N}$ in most soils, and their availability is controlled by soil physical properties, leaching, and microbial activities, more often than not resulting in formation of N-depletion zones in soils (Miller and Cramer, 2004; Jones and Kielland, 2012; Werdin-Pfisterer et al., 2012); upon N limitation, plants develop physiological alterations to enhance nitrogen acquisition (Good et al., 2004; Hermans et al., 2006; Nacry et al., 2013) or farmers apply synthetic fertilizers to ensure yield. The latter often leads to the deterioration of soil physical properties on the one hand, whereas it results in $\mathrm{N}$ losses through leaching (polluting ground-water reservoirs), runoff (deposition in fresh-water bodies, causing eutrophication), $\mathrm{NH}_{3}$ volatilization, and denitrification on the other hand. Excessive $\mathrm{N}$ deposition negatively influences air quality and ecosystem health by impacting human health, unbalancing greenhouse gas emissions, disturbing soil and water chemistry, and narrowing biological diversity (Tilman et al., 2006; Guo et al., 2009; Sutton et al., 2011; Stevens et al., 2015; Liu et al., 2016). Hence, to counter (1) environmental risks and economic losses associated with $\mathrm{N}$-fertilization, and (2) the scarcity of $\mathrm{N}$ in natural soils, it is worth investigating the morphological, physiological, and molecular adaptive alterations adopted by plants to survive in $\mathrm{N}$-limiting environments.

Phosphorus (P), a key component of nucleic acid and phospholipids, is another macronutrient that is essential for plant growth and development. It exists in soils either as inorganic phosphorus $(\mathrm{Pi})$ interacting strongly with divalent and trivalent cations or as organophosphates releasing phosphorus for root uptake upon hydrolysis. In traditional agricultural systems, farmers either rely on the inherent fertility of the soil or the addition of manures and phosphate fertilizers to supply Pi for plant growth (Syers et al., 2008). However, the acquisition of phosphorus from soils is challenging for plants because of the low solubility of phosphates of aluminum, iron, and calcium (Schachtman et al., 1998). Pi also has high sorption capacity to soil particles; thus, its uptake by plants depends upon their ability to find immobile Pi in soils. Hence, the unavailability of $\mathrm{P}$ in soils and agricultural intensification have resulted in a dependency on the application of Pi fertilizers to increase crop yield (Cordell et al., 2009).

Different plants have evolved differential responses to cope with N, P, and other abiotic stresses. Research on the abiotic stress responses of plants has come to the forefront but now needs to be extended beyond maize, rice, wheat or Arabidopsis thaliana to enhance crop diversity. Foxtail millet (Setaria italica L.), thought to be native of South Asia, is one of the oldest cultivated millets around the globe. The cultivation of foxtail millet for human consumption dates back to 4000 years ago (Baltensperger, 1996). China, Russia, India, Africa, and the United States are the regions where it is widely grown. It is being cultivated for food and fodder throughout Eurasia and the Far East. It is primarily grown for hay in the United States and can produce 2.47-8.65 tones ha ${ }^{-1}$ aboveground biomass (Schonbeck and Morse, 2006). Its $\mathrm{C} / \mathrm{N}$ ratio is 44 , and it contains $48 \mathrm{~kg}$ $\mathrm{ha}^{-1} \mathrm{~N}$ in aboveground biomass (Creamer and Baldwin, 1999). It produces high yield with low levels of prussic acid (Sheahan, 2014). In contrast to other millets, foxtail millet can be grown in cooler and droughty regions in spite of having a shallow root system (Hancock Seed, 2014). It is a water-efficient crop: it requires $1 / 3$ less water than maize and can produce one ton of forage in $2 \frac{1}{2}$ inch moisture (Koch, 2002). Foxtail millet is also a preferred choice for the restoration of steep slopes or mine lands because it grows fast and produces more biomass than annual rye (Burger et al., 2009).

Since the release of genome sequences of foxtail millet by the Joint Genome Institute (JGI) of the United States Department of Energy, the importance of this species has been increasingly growing. Owing to its close relationship with bioenergy crops like switch grass (Panicum virgatum), Napier grass (Pennisetum purpureum), and pearl millet (Pennisetum glaucum), foxtail millet is also considered as a model system for biofuel grasses (Doust et al., 2009). Bennetzen et al. (2012) and Zhang et al. (2012) have compiled two full reference genome sequences along with high-density linkage maps with another foxtail millet line and green foxtail and have examined the evolution and mechanisms of $\mathrm{C}_{4}$ photosynthesis in foxtail millet. The availability of the foxtail millet genome provides an important resource for studying $\mathrm{C}_{4}$ photosynthesis in the context of carbon, $\mathrm{N}$, and $\mathrm{P}$ metabolism and nutrient use efficiency. The molecular basis of drought tolerance can also be investigated through drought-associated genes (Zhang et al., 2012). Intensive studies are expected to be conducted on foxtail millet as a model crop for plant nutrient use efficiency, which may benefit agricultural sustainability and food security by enhancing crop diversity (Doebley, 2006). Therefore, the current review will be focusing on 
the abiotic stress responses of foxtail millet, with special emphasis on its responses to low $\mathrm{N}$ and Pi (Figure 1).

\section{FOXTAIL MILLET: A MODEL CROP FOR STRESS BIOLOGY}

Foxtail millet is a herbicide (Zhu et al., 2006) and is a drought and salt-tolerant crop (Jayaraman et al., 2008; Krishnamurthy et al., 2014; Sudhakar et al., 2015). Foxtail millet produces $1 \mathrm{~g}$ of dry mass at the cost of $257 \mathrm{~g}$ of water, which is far less than that required by maize and wheat (Li and Brutnell, 2011). Auxin response factors (ARFs) regulate embryogenesis, leaf expansion and senescence, and lateral root and fruit development by controlling the expression of auxin response genes (Wilmoth et al., 2005). Since ARF1 isolation (Regad et al., 1993), ARFs have been identified in plant species like Arabidopsis, rice, tomato, potato, maize, carrot, wheat, tobacco, and barley. In maize, ARF proteins are involved in the transformation of lipid composition indirectly (Verwoert et al., 1995), and overexpression of ZmARF1 in Arabidopsis enhances growth rates by increasing leaf and seed size (Yuan et al., 2013). Similarly, overexpression of ZmARF2 in Arabidopsis produces larger leaves and seeds and taller plants due to enhanced cell expansion (Wang et al., 2012). ARF proteins play roles in biotic and abiotic stress tolerance in crop plants. Identification of ARF/ARL gene family members in foxtail millet and rice, together with characterization of their structure, organization, duplication and divergence and expression patterns in different tissues, has been reported (Muthamilarasan et al., 2016). A total of 25 ARF genes were identified in foxtail millet diverged from a common ancestor. More efforts are required to investigate ARF genes in specific tissue under a specific stress condition to gain clear clues on tissue-specific and/or stressinducible promoters. WRKYs are one of the largest transcription factor families and contain $\mathrm{W}$-box in their promoter region to control gene expression and regulation in plants (Eulgem et al., 2000). Comprehensive computational approaches have also been used to identify WRKY genes in foxtail millet. Differential expression patterns of candidate SiWRKY genes under abiotic stresses suggest their stress-related regulatory functions (Muthamilarasan et al., 2015).

Foxtail millet responds to abiotic stresses through enhanced biochemical activities like higher levels of antioxidants, reactive oxygen species, and their scavenging enzymes, enzyme activities of catalase and superoxides, and synthesis of osmolytes and their stress-related proteins (Lata et al., 2011b). Aldo-Keto reductases (AKRs) are known to be cytosolic, monomeric oxidoreductases catalyzing NADPH-dependent reduction activities on carbonyl

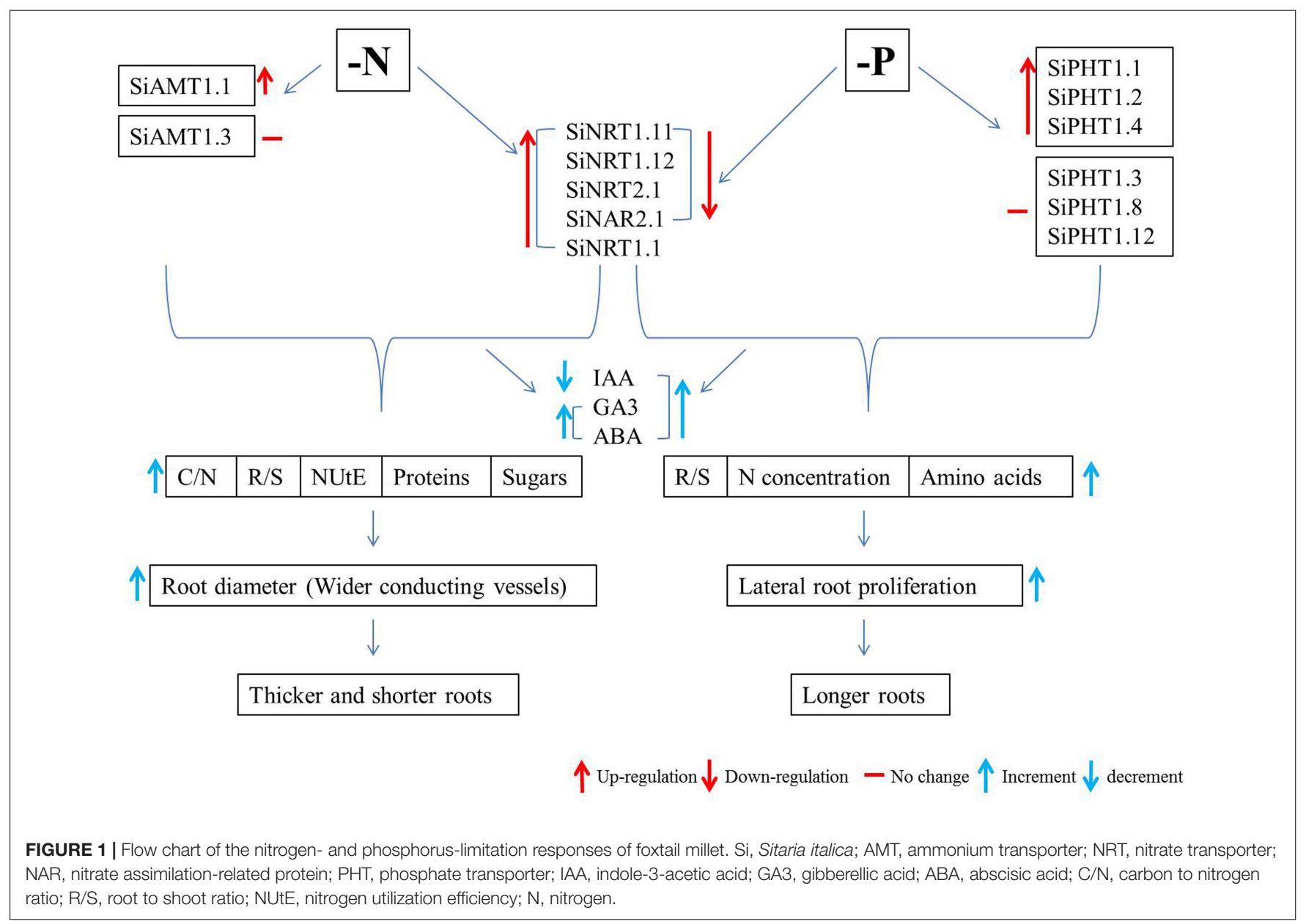


metabolites (Bohren et al., 1989). A broad range of substrates like sugars, prostaglandins, chalcones, aliphatic/aromatic aldehydes, and some toxins can be metabolized by AKRs (Narawongsanont et al., 2012). AKRs are also known for their effective detoxification of reactive carbonyls produced during severe oxidative stress. AKR (MsALR) proteins in transgenic tobacco plants improve tolerance against methylviologen, heavy metals, osmotic stress, and long periods of oxidative stresses induced by drought (Oberschall et al., 2000), cold (Hegedus et al., 2004), and UV radiation (Hideg et al., 2003). In tobacco plants, heterologous expression of OsAKR1 shows better tolerance against heat (Turoczy et al., 2011). Overexpression of Arabidopsis AKR4C9 in barley enhances freezing tolerance and post-frost regenerative capacity (Eva et al., 2014). Moreover, overexpression of peach AKR1 (PpAKR1) in Arabidopsis enhances salt tolerance compared to wild type plants (Kanayama et al., 2014). In contrast, GmAKR1 protein overproduction inhibits nodule development in the hairy roots of soybean (Hur et al., 2009). Malondialdehyde (MDA), a product of lipid peroxidation, is a biomarker of oxidative stresses (Bailly et al., 1996); lower MDA levels indicate better oxidative stress tolerance. OSAKR1 overexpression in tobacco lowers levels of MDA and methylglyoxal (MG) in leaf tissues under chemical and heat stress treatments (Turoczy et al., 2011). Foxtail millet $A K R 1$ is a promising stress-responsive gene that modulates and enhances stress tolerance in major crops (Kirankumar et al., 2016). Thus, investigation of the functions of AKR in reactive carbonyl detoxification and the promotion of abiotic stress tolerance in foxtail millet is of interest.

Reactive oxygen species (ROS) are involved in various signal transduction pathways (Apel and Hirt, 2004; Laloi et al., 2004) under stress conditions (Mustilli et al., 2002; Neill et al., 2002). ROS also regulate gene expression under N, P, and potassium deficiency (Shin and Schachtman, 2004; Shin et al., 2005). Superoxide dismutase converts $\mathrm{O}_{2}{ }^{-}$, an important component of ROS, into $\mathrm{H}_{2} \mathrm{O}_{2}$ (Fridovich, 1997). Several classical peroxidases like ascorbate peroxidase (APX), glutathione peroxidases, and catalase (CAT) quench the resulting $\mathrm{H}_{2} \mathrm{O}_{2}$. APX and glutathione reductase (GR) detoxify $\mathrm{H}_{2} \mathrm{O}_{2}$ in green leaves (Sofo et al., 2015). They likely act as dehydration stress-responsive components in foxtail millet (Lata et al., 2011b). Maintenance of membrane stability, relative water content, higher levels of APX, CAT, and GR activities, and lower levels of lipid peroxidation and electrolyte provides resistance against the drought stress in foxtail millet (Lata et al., 2011b). Upregulation of phospholipid hydroperoxide glutathione peroxidase (PHGPX) in salt-tolerant foxtail millet lines suggests its role in salt resistance (Sreenivasulu et al, 2004). Aldose reductase is involved in sorbitol biosynthesis and the detoxification of 4-hydroxynon-2-enal (a lipid peroxidation product) in foxtail millet under salt stress; glutathione S-transferase also catalyzes 4-hydroxynon-2-enal detoxification under stress conditions (Veeranagamallaiah et al., 2009). Differentially expressed ESTs and peptides between salt-tolerant and sensitive cultivars (Puranik et al., 2011a), along with other proteins involved in the $\mathrm{NaCl}$ stress (Veeranagamallaiah et al., 2008), can be extended to future studies in foxtail millet.
APETALA 2/ethylene responsive element binding factor (AP2/ERF) superfamily members contain a characteristic conserved AP2 domain to bind the core DRE (Dehydration Responsive Element) (5'-A/GCCGAC-3') cis-acting element in the promoter region of target genes (Yamaguchi-Shinozaki and Shinozaki, 1994; Yamaguchi-Shinozaki and Shinozaki, 2006). The single nucleotide polymorphism (SNP) of a dehydrationresponsive element binding (DREB) gene is associated with stress tolerance (Lata et al., 2011a). A similar SNP accounts for $27 \%$ of variations in stress-induced lipid peroxidation in foxtail millet (Lata and Prasad, 2013). Re-sequencing of foxtail millet may identify vast libraries of SNPs and other markers (Bai et al., 2013; Jia et al., 2013). Small interfering RNAs and non-coding RNAs also have their regulatory roles in drought responses in foxtail millet (Qi et al., 2013). In addition, late embryogenesis-abundant proteins protect higher plants against environmental stresses; SiLEA14 plays an important role in resisting abiotic damage in foxtail millet (Wang et al., 2014). Its small genome ( $\sim 40 \mathrm{Mbp}$; Bennetzen et al., 2012; Zhang et al., 2012) and a wide array of stress responses make foxtail millet a model cereal crop for stress biology and functional genomics (Table 1).

\section{RESPONSES OF FOXTAIL MILLET TO N LIMITATION}

Roots are the means by which plants take up nutrients; hence, root architectural modifications become vital to explore $\mathrm{N}$ under its low availability. Different crop species respond to external low$\mathrm{N}$ conditions differentially. Legumes, for example, develop root nodules to capture atmospheric $\mathrm{N}$ through $\mathrm{N}$-fixation (Postgate, 1998), whereas cereals such as maize enhance their root surface area by means of increasing axial and lateral root length to access $\mathrm{N}$ in a heterogeneous environment (Wang et al., 2003; Chun et al., 2005). As mentioned before, plants undergo these morphological and physiological alterations to maximize their $\mathrm{N}$ use efficiency (NUE), which can be discussed as either $\mathrm{N}$ utilization efficiency (NUtE) or N uptake (acquisition) efficiency (Garnett et al., 2009; $\mathrm{Xu}$ et al., 2012; Wang et al., 2019). At one extreme, the carbon to $\mathrm{N}$ ratio and biomass accumulation (dry weight; root to shoot ratio) in roots of foxtail millet increase under low $\mathrm{N}$, which suggests that its higher $\mathrm{N}$ utilization efficiency contributes to maximize its $\mathrm{N}$ use efficiency, whereas on the other extreme, foxtail millet responds to increase $\mathrm{N}$ translocation efficiency by root thickening. These adaptive responses of foxtail millet to low $\mathrm{N}$ signals along with regulation of $\mathrm{N}$ uptake activities through $\mathrm{N}$ influx transporters located at the plasma membrane eventually maximize $\mathrm{N}$ acquisition efficiency (Nadeem et al., 2018).

Surprisingly, foxtail millet produces a specific root length (SRL) of $46852 \mathrm{~cm} \mathrm{~g}^{-1}$ of root dry weight under low $\mathrm{N}$ (Nadeem et al., 2018), which is 10 times that of maize seedlings under similar conditions (Han et al., 2015). In addition to the SRL, the average root diameter of low- $\mathrm{N}$ foxtail millet also increases (Nadeem et al., 2018). Resource absorption and transportation are two important resource acquisition processes for roots, with the former being used by cortex and the latter by stele (Guo et al., 2008). The ratio of cortex to stele thickness determines 
TABLE 1 | Genes functionally characterized in foxtail millet.

\begin{tabular}{|c|c|c|}
\hline Gene & Functions & References \\
\hline SET domain genes & Abiotic stress tolerance & Yadav et al., 2016 \\
\hline PHT1 gene family & Phosphate transporters & Ceasar et al., 2014 \\
\hline Argonaute protein 1 encoding gene & Regulation of stress responses & Liu et al., 2016 \\
\hline Abscisic acid stress ripening gene (ASR) & Tolerance to drought and oxidative stresses & Feng et al., 2016 \\
\hline Autophagy-related gene (ATG) & Tolerance to nitrogen starvation and drought stresses & Li et al., 2015 \\
\hline Late embryogenesis abundant protein (LEA) & Tolerance to salt, osmotic, and drought stresses & Wang et al., 2014 \\
\hline ABA-responsive DRE-binding protein (ARDP) & Tolerance to salt and drought stresses & Li et al., 2014 \\
\hline WD-40 & Associated with dehydration stress-responsive pathway & Mishra et al., 2012 \\
\hline Acetyl-CoA carboxylase & Resistance to sethoxydim herbicide & Dong et al., 2011 \\
\hline Dehydration-responsive element-binding protein 2 (DREB2) & Dehydration tolerance & Lata et al., $2011 \mathrm{a}$ \\
\hline NAC transcription factor & Salinity tolerance & Puranik et al., 2011b \\
\hline Si69 & Aluminum tolerance & Zhao et al., 2009 \\
\hline Aldose reductase & Associated with salinity stress-responsive pathway & Veeranagamallaiah et al., 2009 \\
\hline Glutamine synthetase Pyrroline-5-carboxylate reductase & & Veeranagamallaiah et al., 2007 \\
\hline 12-oxophytodienoic acid reductase (OPR1) & Drought tolerance & Zhang et al., 2007 \\
\hline Photosystem II D1protein & Atrazine resistance & Jia et al., 2007 \\
\hline Phospholipid hydroperoxide glutathione peroxidase (PHGPX) & Associated with salinity tolerance & Sreenivasulu et al., 2004 \\
\hline Nuclear factor-Y (SiNF-YA1, SiNFYB8) genes & Drought and salt tolerance & Feng et al., 2015 \\
\hline Nitrate transporters (SiNRT), Ammonium transporters (SiAMT) & Nitrate and ammonium uptake and transport & Nadeem et al., 2018 \\
\hline Phosphate transporters (SiPHP) & Phosphate transport & Ahmad et al., 2018 \\
\hline
\end{tabular}

the suitability of a plant species for adapting to a certain environment for favorable resource distribution. The increased thickness of foxtail millet roots under low $\mathrm{N}$ indicates the anatomical modification of stele, where it can accommodate more conduits like vessels and tracheid for efficient transport of $\mathrm{N}$ and metabolites.

Hormones help plants to adapt to environmental cues through the regulation of growth and development (Wolters and Jürgens, 2009; Marsch-Martinez and de Folter, 2016). Indole-3-acetic acid (IAA) regulates primary and lateral root growth (Sabatini et al., 1999; Casimiro et al., 2001), whereas cytokinins (CKs) influence apical root dominance (Aloni et al., 2006). IAA and CK accumulation decreases during root shortening in foxtail millet under low $\mathrm{N}$ despite enhanced carbon allocation toward the roots (higher dry mass and $\mathrm{C} / \mathrm{N}$ ratio). Contrary to IAA and CKs, gibberellic acid (GA3) concentrations increase in the root and shoot of foxtail millet (Nadeem et al., 2018). Accumulation of GA3 antagonistic to IAA and CKs could have contributed to root thickening (increased root diameter) through tissue differentiation and anatomical modifications to roots (Yamaguchi, 2008). Abscisic acid (ABA) is known to be an internal signal of stress responses (Wilkinson and Davies, 2002; Kiba et al., 2011). Higher levels of ABA in N-deprived roots (Nadeem et al., 2018) is rather a stress response of foxtail millet that needs to be further dissected to determine the underlying mechanisms.

Sensing the external nutritional alterations, certain specific proteins act as channels, pumps, or transporters in roots to acquire nutrients from their vicinity and transport them within the root or along the vasculature for long-distance source-tosink transport (Tegeder and Masclaux-Daubresse, 2018). To transport nitrate $\left(\mathrm{NO}_{3}^{-}\right)$, a nutrient as well as a signaling molecule for plant growth and root system modifications (Vidal and Gutiérrez, 2008; Krouk et al., 2010; Alvarez et al., 2012), plants have evolved a high-affinity transport system (HATS) and low-affinity transport system (LATS) (Crawford and Glass, 1998). NRT2.1 belongs to the high-affinity nitrate transport system (Li et al., 2007), whereas NRT1.1 is a sensor as well as a dual-affinity nitrate transporter (transceptor) in Arabidopsis (Tsay et al., 1993; Liu and Tsay, 2003). NRT2 transporters interact with nitrate accessory protein NAR2.1 (NAR2 likeproteins) for nitrate absorption. Upregulation of expressions of SiNRT1.1, SiNRT2.1, and SiNAR2.1, together with root architectural modifications, optimizes $\mathrm{N}$ acquisition in foxtail millet, which is confirmed by enhanced ${ }^{15} \mathrm{~N}$ influx into roots (Nadeem et al., 2018). Once nitrate is absorbed, the next phase is its redistribution or translocation from root to shoot and from mature expanded leaves to the youngest leaves (Okamoto et al., 2006; Orsel et al., 2006; Tsay et al., 2007; Miller et al., 2009). In this regard, NRT1.11 and NRT1.12 mediate xylem to phloem loading and redistribution of nitrate in Arabidopsis (Arabidopsis thaliana) leaves with normal nitrate provision (Hsu and Tsay, 2013). Foxtail millet seedlings supplied with only $0.02 \mathrm{mM}$ of $\mathrm{NH}_{4} \mathrm{NO}_{3}$ for 7 days show nitrate redistribution in the shoot through upregulation of SiNRT1.11 and SiNRT1.12 expressions, indicating an extraordinary ability to adapt to extreme $\mathrm{N}$ limitation. Alongside nitrate uptake, ammonium uptake and transport are controlled by ammonium transporters (AMTs) (Loqué and von Wirén, 2004). SiAMT1.1 accelerates N acquisition by upregulating its expression (Nadeem et al., 2018).

Interlinked carbon and $\mathrm{N}$ metabolism generally give rise to balanced carbohydrates to $\mathrm{N}$-metabolites ratios in plant tissues. However, $\mathrm{N}$ limitation leads to higher carbon/ $\mathrm{N}$ ratios (Sun et al., 2002; Reich et al., 2006; Taub and Wang, 2008). In 
foxtail millet, the root and shoot maintain the balance between free amino acids and total soluble sugar concentrations owing to low $\mathrm{N}$ concentrations of these tissues under low external $\mathrm{N}$ provision. Interestingly, concentrations of total soluble proteins in roots increase, in contrast to those in shoots (Nadeem et al., 2018), indicating the probable role of proteins (enzymes in particular) in the regulation of carbon and $\mathrm{N}$ metabolism-related cellular activities at the tissue level.

\section{FOXTAIL MILLET RESPONSES TO Pi STARVATION}

Plants have evolved strategies for enhancing their P-uptake capacity either through arbuscular mycorrhizal symbiosis or modification of the root system architecture (Marschner, 1995; Lambers et al., 2008; Cheng et al., 2011). As explained previously, root system modification is the primary adaptive strategy of plants coping with low availability of nutrients. Low mobility of $\mathrm{Pi}$ in soils favors shallow root plants (Panigrahy et al., 2009; Péret et al., 2011; Li et al., 2012; Shi et al., 2013). In Arabidopsis thaliana, reduced Pi metabolism (Nussaume et al., 2011; Wang et al., 2011), indirect low-P-mediated stress effects (Thibaud et al., 2010), and genetic control of root responses to low $\mathrm{P}$ (Svistoonoff et al., 2007; Ticconi et al., 2009) inhibit primary root growth (Abel, 2011; Niu et al., 2013; Giehl et al., 2014). In addition, blue light suppresses elongation of the primary root of petri dish-grown Arabidopsis seedlings under Pi deficiency (Zheng et al., 2019). Thus, environmental factors collectively reshape root structure in response to $\mathrm{Pi}$ starvation.

Plant responses to $\mathrm{Pi}$ starvation could also be genotypedependent (Reymond et al., 2006). In monocots like rice and barley, low $\mathrm{Pi}$ has a less pronounced effect on primary root growth, perhaps due to high $\mathrm{P}$ reserves in seeds (CalderónVázquez et al., 2011), whereas primary root growth of maize is stimulated under low $\mathrm{Pi}$ ( $\mathrm{Li}$ et al., 2012). In contrast with the primary root inhibition, lateral root formation in plants is enhanced by low Pi (Williamson et al., 2001; Hodge, 2004; PérezTorres et al., 2008). Foxtail millet, on the other hand, develops a larger root system in terms of crown root length and lateral root number, length, and density under Pi deficiency (Ahmad et al., 2018), which is in total contrast to what is observed under low $\mathrm{N}$ (Nadeem et al., 2018). The enlargement of the root system in response to low $\mathrm{Pi}$ and reduction under low $\mathrm{N}$ in foxtail millet could be due to the immobile and mobile nature of $\mathrm{Pi}$ and nitrate, respectively; longer roots can reach immobile $\mathrm{Pi}$ at its location, and shorter roots can intercept mobile nitrate in the microenvironment of the rhizosphere. This root enlargement of foxtail millet couples with hormonal enhancements (auxin and GA3) and increase in root to shoot ratio due to the allocation of carbon to the P-deficient root.

A larger root system functions to enhance $\mathrm{Pi}$ acquisition by transporters (Rausch and Bucher, 2002). Pi transporters are mostly conserved across cereal crops (Rakshit and Ganapathy, 2014). Pi limitation stimulates transcription of PHT1 members (Mudge et al., 2002; Rae et al., 2003) and induces OsPHT1.2 expression in the stele and lateral roots, along with upregulation of OsPHT1.4, probably to improve Pi uptake through roots and translocation to the shoot (Ye et al., 2015; Zhang et al., 2015). Substantial upregulation of SiPHT1.1, SiPHT1.2, and SiPHT1.4 expression in root tissues possibly preconditions for enhanced $\mathrm{Pi}$ uptake to replenish the internal P-reserves, whereas downregulation of SiPHT1.3 expression probably assists with the retention of $\mathrm{Pi}$ in the shoot (Ahmad et al., 2018). On the other end, respective down-regulation of expression of SiNRT2.1 and SiNAR2.1 (in roots) and that of SiNRT1.11 and SiNRT1.12 (in shoots) (Ahmad et al., 2018) helps balance the N/P ratio within permissible limits for proper root and shoot functionality (Aerts and Chapin, 2000). Such correlative interpretation of the expression of SiPHRs in relation to Pi uptake and sourcesink remobilization under low Pi calls for in-depth mechanistic dissection (Jia et al., 2011; Ceasar et al., 2014). Alternatively, foxtail millet uses internal $\mathrm{Pi}$ reserves for higher utilization efficiency (Rose et al., 2011).

Interestingly, the reduction of SPAD values in the foxtail millet shoot is in contrast to differential accumulation of free amino acids (higher in shoot and root) and total soluble proteins (lower in shoot and root) under low $\mathrm{Pi}$ provision (Ahmad et al., 2018). These variations in the accumulation of $\mathrm{N}$-metabolites upon low $\mathrm{P}$ suggest a potential link between $\mathrm{N}$ and $\mathrm{P}$ nutrition at the physiological level. Nutrient provision affects biomass allocation within plants (Poorter et al., 2012). $\mathrm{N}$ and $\mathrm{P}$ are both considered as the limiting factors in plant growth and development; therefore, the $\mathrm{N} / \mathrm{P}$ ratio plays a critical role in resource distribution (Graham and Mendelssohn, 2016). The uptake of $\mathrm{N}$ and $\mathrm{P}$ is adjusted by whole-plant signaling to balance $\mathrm{N} / \mathrm{P}$ ratios between plant tissues (Imsande and Touraine, 1994; Raghotama, 1999; Forde, 2002). To maintain the $\mathrm{N} / \mathrm{P}$ ratio, foxtail millet reduces $\mathrm{N}$ translocation toward the shoot under Pi limitation (Ahmad et al., 2018), similar to the terrestrial plants that adapt to low-N conditions by decreasing Pi uptake (Aerts and Chapin, 2000). $\mathrm{P}$ and $\mathrm{N}$ signals are indeed integrated by nitrateinducible GARP-type transcriptional repressor 1 (NIGT1) in Arabidopsis; PHR1 promotes the expression of NIGT1-clade genes under low $\mathrm{P}$, which in turn down-regulates NRT2.1 expression to reduce $\mathrm{N}$ uptake (Maeda et al., 2018). NIGT1 expression is stimulated when $\mathrm{N}$ availability is high in order to repress $\mathrm{N}$ starvation genes (Kiba et al., 2018). NIGT1 also regulates $\mathrm{Pi}$ starvation responses by directly repressing expression of $\mathrm{Pi}$ starvation-responsive genes and NRT2.1 to equilibrate $\mathrm{N}$ and $\mathrm{P}$ (Maeda et al., 2018). The potential involvement of the PHR1-NIGT1-NRT2.1 pathway in low $\mathrm{P}$ responses of foxtail millet and subsequent readouts needs to be further studied in future.

\section{CONCLUSION}

Foxtail millet has been studied for its structural and functional genomics for the purpose of developing genetic and genomic resources and delineating the physiology and molecular biology of stress tolerance, especially drought and salinity stress tolerance. Apart from its adaptation to drought and salinity, foxtail millet 
is also an $\mathrm{N}$ - and P-efficient crop. In parallel to those in major cereals, studies should be conducted to develop nutrient-efficient and environment friendly cultivars of foxtail millet. Its small genome size, short life cycle and inbreeding nature make foxtail millet a perfect choice for a model crop for studies of a broad range of plant nutritional biology research. This review presents a unique perspective of the adaptation of foxtail millet to low $\mathrm{N}$ and low $\mathrm{P}$ along with a brief background on various abiotic stress tolerance strategies. It can serve as a base to plan future studies in the field of plant nutritional genomics using foxtail millet as a model crop.

\section{REFERENCES}

Abel, S. (2011). Phosphate sensing in root development. Curr. Opin. Plant Biol. 14, 303-309. doi: 10.1016/j.pbi.2011.04.007

Aerts, R., and Chapin, F. S. (2000). The mineral nutrition of wild plants revisited: a re-evaluation of processes and patterns. Adv. Ecol. Res. 30, 1-67. doi: 10.1016/ S00652504(08)60016-1

Ahmad, Z., Nadeem, F., Wang, R., Diao, X., Han, Y., Wang, X., et al. (2018). A larger root system is coupled with contrasting expression patterns of phosphate and nitrate transporters in foxtail millet [Setaria italica (L.) Beauv.] under phosphate limitation. Front. Plant Sci. 9:1367. doi: 10.3389/fpls.2018. 01367

Aloni, R., Aloni, E., Langhans, M., and Ullrich, C. I. (2006). Role of cytokinin and auxin in shaping root architecture: regulating vascular differentiation, lateral root initiation, root apical dominance and root gravitropism. Ann. Bot. 97, 883-893. doi: 10.1093/aob/mcl027

Alvarez, J. M., Vidal, E. A., and Gutiérrez, R. A. (2012). Integration of local and systemic signaling pathways for plant N responses. Curr. Opin. Plant Biol. 15, 185-191. doi: 10.1016/j.pbi.2012.03.009

Apel, K., and Hirt, H. (2004). Reactive oxygen species: metabolism, oxidative stress, and signal transduction. Annu. Rev. Plant Biol. 55, 373-399. doi: 10.1146/ annurev.arplant.55.031903.141701

Bai, H., Cao, Y., Quan, J., Dong, L., Li, Z., Zhu, Y., et al. (2013). Identifying the genome-wide sequence variations and developing new molecular markers for genetics research by resequencing a landrace cultivar of foxtail millet. PLoS One 8:e73514. doi: 10.1371/journal.pone.0073514

Bailly, C., Benamar, A., and Corbineau, Y. (1996). Changes in malondialdehyde content and in superoxide dismutase, catalase and glutathione reductase activities in sunflower seeds as related to deterioration during accelerated aging. Physiol. Plant. 97, 104-110. doi: 10.1111/j.1399-3054.1996.tb00485.x

Baltensperger, D. D. (1996). "Foxtail and proso millet," in Progress in New Crops, ed. J. Janick, (Alexandria, VA: ASHS Press).

Bechtold, U., and Field, B. (2018). Molecular mechanisms controlling plant growth during abiotic stress. J. Exp. Bot. 69, 2753-2758. doi: 10.1093/jxb/ery157

Bennetzen, J. L., Schmutz, J., Wang, H., Percifield, R., Hawkins, J., Pontaroli, A. C., et al. (2012). Reference genome sequence of the model plant Setaria. Nat. Biotechnol. 30, 555-561. doi: 10.1038/nbt.2196

Bohren, K. M., Bullock, B., Wermuth, B., and Gabbay, K. M. (1989). The Aldo-Keto Reductase Superfamily: cDNAs and deduced amino acid sequences of human aldehyde and aldose reductase. J. Biol. Chem. 264, 9547-9551.

Boyer, J. S. (1982). Plant productivity and environment. Science 218, 443-448. doi: 10.1126/science.218.4571.443

Burger, J., Davis, V., Franklin, J., Zipper, C., Skousen, J., Barton, C., et al. (2009). Tree-Compatible Ground Covers for Reforestation And Erosion Control. Forest Reclamation Advisory No. 6, Appalachian Regional Reforestation Initiative (ARRI). Available at: http://arri.osmre.gov/PDFs/Pubs/FRA_No.6_7-24-09.pdf (accessed October 12, 2019).

Calderón-Vázquez, C., Sawers, R. J., and Herrera-Estrella, L. (2011). Phosphate deprivation in maize: genetics and genomics. Plant Physiol. 156, 1067-1077. doi: 10.1104/pp.111.174987

Casimiro, I., Marchant, A., Bhalerao, R. P., Beeckman, T., Dhooge, S., Swarup, R., et al. (2001). Auxin transport promotes Arabidopsis lateral root initiation. Plant Cell 13, 843-852. doi: $10.1105 /$ tpc. 13.4 .843

\section{AUTHOR CONTRIBUTIONS}

$\mathrm{FN}, \mathrm{ZA}, \mathrm{XD}$, and $\mathrm{XL}$ conceived and wrote the review. FN, MU, RW, XD, and XL revised the manuscript. All authors have approved the final manuscript.

\section{FUNDING}

This work was supported by the National Natural Science Foundation of China (31972491 and 31772385).

Ceasar, S. A., Hodge, A., Baker, A., and Baldwin, S. A. (2014). Phosphate concentration and arbuscular mycorrhizal colonisation influence the growth, yield and expression of twelve PHT1 family phosphate transporters in foxtail millet (Setaria italica). PLoS One 9:e108459. doi: 10.1371/journal.pone.0108459

Cheng, L., Bucciarelli, B., Shen, J., Allan, D. L., and Vance, C. P. (2011). Update on white lupin cluster roots acclimation to phosphorus deficiency. Plant Physiol. 156, 1025-1032. doi: 10.1104/pp.111. 175174

Chun, L., Chen, F., Zhang, F., and Mi, G. (2005). Root growth, nitrogen uptake and yield formation of hybrid maize with different $\mathrm{N}$ efficiency. Plant Nutr. Fertil. Sci. 11, 615-619.

Cordell, D., Drangert, J. O., and White, S. (2009). The story of phosphorus: global food security and food for thought. Glob. Environ. Change. 19, 292-305. doi: 10.1016/j.gloenvcha.2008.10.009

Cramer, G. R. (2010). Abiotic stress and plant responses from the whole vine to the genes. Aust. J. Grape Wine Res. 16, 86-93. doi: 10.1111/j.1755-0238.2009. 00058.x

Crawford, N. M., and Glass, A. D. M. (1998). Molecular and physiological aspects of nitrate uptake in plants. Trends Plant Sci. 3, 389-395. doi: 10.1016/s13601385(98)01311-9

Creamer, N. G., and Baldwin, K. R. (1999). Summer Cover Crops. Raleigh, NC: NC State University.

Doebley, J. (2006). Unfallen grains: how ancient farmers turned weeds into crops. Science 312, 1318-1319. doi: 10.1126/science.1128836

Dong, Z., Zhao, H., He, J., Huai, V., Lin, H., Zheng, J., et al. (2011). Overexpression of a foxtail millet Acetyl-CoA carboxylase gene in maize increases sethoxydim resistance and oil content. Afr. J. Biotechnol. 10, 3986-3995. doi: 10.5897/AJB11. 053

Doust, A. N., Kellogg, E. A., Devos, K. M., and Bennetzen, J. L. (2009). Foxtail millet: a sequence-driven grass model system. Plant Physiol. 149, 137-141. doi: 10.1104/pp.108.129627

Eulgem, T., Rushton, P. J., Robatzek, S., and Somssich, I. E. (2000). The WRKY superfamily of plant transcription factor. Trends Plant Sci. 5, 199-206. doi: 10.1016/s1360-1385(00)01600-9

Eva, C., Zelenyanszki, H., Farkas, R. T., and Tamas, L. (2014). Transgenic barley expressing the Arabidopsis AKR4C9 Aldo-Keto Reductase enzyme exhibits enhanced freezing tolerance and regenerative capacity. S. Afr. J. Bot. 93, 179-184. doi: 10.1016/j.sajb.2014.04.010

Feng, Z. J., He, G. H., Zheng, W. J., Lu, P. P., Chen, M., Gong, Y. M., et al. (2015). Foxtail millet NF-Y families: genome-wide survey and evolution analyses identified two functional genes important in abiotic stresses. Front. Plant Sci. 6:1142. doi: 10.3389/fpls.2015.01142

Feng, Z. J., Xu, Z. S., Sun, J., Li, L. C., Chen, M., Yang, G. X., et al. (2016). Investigation of the ASR family in foxtail millet and the role of ASRI in drought/oxidative stress tolerance. Plant Cell Rep. 35, 115-128. doi: 10.1007/ s00299-015-1873-y

Forde, B. G. (2002). The role of long-distance signalling in plant responses to nitrate and other nutrients. J. Exp. Bot. 53, 39-43. doi: 10.1093/jexbot/53.366.39

Fridovich, I. (1997). Superoxide anion radical (O2-), superoxide dismutases, and related matters. J. Biol. Chem. 272, 18515-18517. doi: 10.1074/jbc.272.30.18515

Garnett, T., Conn, V., and Kaiser, B. N. (2009). Root based approaches to improving nitrogen use efficiency in plants. Plant Cell Environ. 32, 1272-1283. doi: 10.1111/j.1365-3040.2009.02011.x 
Giehl, R. F., Gruber, B. D., and von Wirén, N. (2014). It's time to make changes: modulation of root system architecture by nutrient signals. J. Exp. Bot. 65, 769-778. doi: 10.1093/jxb/ert421

Giehl, R. F., and von Wirén, N. (2014). Root nutrient foraging. Plant Physiol. 166, 509-517. doi: 10.1104/pp.114.245225

Good, A. G., Shrawat, A. K., and Muench, D. G. (2004). Can less yield more? Is reducing nutrient input into the environment compatible with maintaining crop production? Trends Plant Sci. 9, 597-605. doi: 10.1016/j.tplants.2004.10. 008

Graham, S. A., and Mendelssohn, I. A. (2016). Contrasting effects of nutrient enrichment on below-ground biomass in coastal wetlands. J. Ecol. 104, 249-260. doi: 10.1111/1365-2745.12498

Guo, D., Xia, M., Wei, X., Chang, W., Liu, Y., and Wang, Z. (2008). Anatomical traits associated with absorption and mycorrhizal colonization are linked to root branch order in twenty-three Chinese temperate tree species. New Phytol. 180, 673-683. doi: 10.1111/j.1469-8137.2008.02573.x

Guo, X., Sun, W., Wei, W., Yang, J., Kang, Y., Wu, J., et al. (2009). Effects of NPK on physiological and biochemical characteristics of winter rape seed in northwest cold and drought region. Acta Agric. Boreali-Occident. Sin. 2:027.

Han, J. N., Wang, L. F., Zheng, H. Y., Pan, X. Y., Li, H. Y., Chen, F. J., et al. (2015). ZD958 is a low-nitrogen-efficient maize hybrid at the seedling stage among five maize and two teosinte lines. Planta 242, 935-949. doi: 10.1007/s00425-0152331-3

Hancock Seed (2014). German Foxtail Millet Seed. Dade City, FL: Hancock Seed Company.

Hegedus, A., Erdei, S., Janda, T., Toth, E., Horvath, G., and Dudits, D. (2004). Transgenic tobacco plants overproducing alfalfa aldose/aldehyde reductase show higher tolerance to low temperature and cadmium stress. Plant Sci. 166, 1329-1333. doi: 10.1016/j.plantsci.2004.01.013

Hermans, C., Hammond, J. P., White, P. J., and Verbruggen, N. (2006). How do plants respond to nutrient shortage by biomass allocation? Trends Plant Sci. 11, 610-617. doi: 10.1016/j.tplants.2006.10.007

Hideg, E., Nagy, T., Oberschall, A., Dudits, D., and Vass, I. (2003). Detoxification function of aldose/aldehyde reductase during drought and ultra violet-b (230$320 \mathrm{~nm}$ ) stresses. Plant Cell Environ. 26, 513-522. doi: 10.1046/j.1365-3040. 2003.00982.x

Hodge, A. (2004). The plastic plant: root responses to heterogeneous supplies of nutrients. New Phytol. 162, 9-24. doi: 10.1111/j.1469-8137.2004.01015.x

Hsu, P. K., and Tsay, Y. F. (2013). Two phloem nitrate transporters, NRT1.11 and NRT1.12 are important for redistributing xylem born nitrate to enhance plant growth. Plant Physiol. 163, 844-856. doi: 10.1104/pp.113.226563

Hur, Y., Shin, K., Kim, S., Nam, K. H., Lee, M., Chun, J., et al. (2009). Overexpression of GmAKR1 a stress-induced aldo-keto reductase from soybean, retards nodule development. Mol. Cells 27, 217-223. doi: 10.1007/ s10059-009-0027- $\mathrm{x}$

Imsande, J., and Touraine, B. (1994). $\mathrm{N}$ demand and the regulation of nitrate uptake. Plant Physiol. 105, 3-7. doi: 10.1104/pp.105.1.3

Jayaraman, A., Puranik, S., Rai, N. K., Vidapu, S., Sahu, P. P., Lata, C., et al. (2008). cDNA-AFLP analysis reveals differential gene expression in response to salt stress in foxtail millet (Setaria italica L.). Mol. Biotechnol. 40, 241-251. doi: 10.1007/s12033-008-90814

Jia, G., Huang, X., Zhi, H., Zhao, Y., Zhao, Q., Li, W., et al. (2013). A haplotype map of genomic variations and genome-wide association studies of agronomic traits in foxtail millet (Setaria italica). Nat. Genet. 45, 957-961. doi: 10.1038/ng. 2673

Jia, H., Ren, H., Gu, M., Zhao, J., Sun, S., Zhang, X., et al. (2011). The phosphate transporter gene $O s P h t 1 ; 8$ is involved in phosphate homeostasis in rice. Plant Physiol. 156, 1164-1175. doi: 10.1104/pp.111.175240

Jia, X., Shi, Y. S., Song, Y. C., Wang, G. Y., Wang, T. Y., and Li, Y. (2007). Development of EST-SSR in foxtail millet (Setaria italica). Genet. Resour. Crop Evol. 54, 233-236. doi: 10.1007/s10722-006-9139-8

Jones, D. L., and Kielland, K. (2012). Amino acid, peptide and protein mineralization dynamics in a taiga forest soil. Soil Biol. Biochem. 55, 60-69. doi: 10.1016/j.soilbio.2012.06.005

Kanayama, Y., Mizutani, R., Yaguchi, S., Hojo, A., Ikeda, H., Nishiyama, M., et al. (2014). Characterization of an uncharacterized aldo-keto reductase gene from peach and its role in abiotic stress tolerance. Phytochemistry 104, 30-36. doi: 10.1016/j.phytochem.2014.04.008
Kiba, T., Inaba, J., Kudo, T., Ueda, N., Konishi, M., Mitsuda, N., et al. (2018). Repression of nitrogen starvation responses by members of the arabidopsis GARP-Type transcription factor NIGT1/HRS1 subfamily. Plant Cell 30, 925-945. doi: 10.1105/tpc.17.00810

Kiba, T., Kudo, T., Kojima, M., and Sakakibara, H. (2011). Hormonal control of nitrogen acquisition: roles of auxin, abscisic acid, and cytokinin. J. Exp. Bot. 62, 1399-1409. doi: 10.1093/jxb/erq410

Kirankumar, T. V., Madhusudhan, K. V., Nareshkumar, A., Kiranmai, K., Lokesh, U., Venkatesh, B., et al. (2016). Expression analysis of Aldo-Keto Reductase 1 (AKR1) in foxtail millet (Setaria italica L.) subjected to abiotic stresses. Am. J. Plant Sci. 7, 500-509. doi: 10.4236/ajps.2016.73044

Koch, D. W. (2002). Foxtail Millet-Management for Supplemental and Emergency Forage. University of Wyoming, Cooperative Extension Service, B-1122.3. Available at: http://www.wyomingextension.org/agpubs/pubs/B1122-3.pdf (accessed October 10, 2019).

Krishnamurthy, L., Upadhyaya, H. D., Gowda, C. L. L., Kashiwagi, J., Purushothaman, R., Singh, S., et al. (2014). Large variation for salinity tolerance in the core collection of foxtail millet (Setaria italica (L.) P. Beauv.) germplasm. Crop Pasture Sci. 65, 353-361. doi: 10.1071/CP13282

Krouk, G., Crawford, N. M., Coruzzi, G. M., and Tsay, Y. F. (2010). Nitrate signaling: adaptation to fluctuating environments. Curr. Opin. Plant Biol. 13, 265-272. doi: 10.1016/j.pbi.2009.12.003

Laloi, C., Apel, K., and Danon, A. (2004). Reactive oxygen signalling: the latest news. Curr. Opin. Plant Biol. 7, 323-328. doi: 10.1016/j.pbi.2004.03.005

Lambers, H., Raven, J. A., Shaver, G. R., and Smith, S. E. (2008). Plant nutrientacquisition strategies change with soil age. Trends Ecol. Evol. 23, 95-103. doi: 10.1016/j.tree.2007.10.008

Lata, C., Bhutty, S., Bahadur, R. P., Majee, M., and Prasad, M. (2011a). Association of an SNP in a novel DREB2-like gene SiDREB2 with stress tolerance in foxtail millet [Setaria italica (L.)]. J. Exp. Bot. 62, 3387-3401. doi: 10.1093/jxb/err016

Lata, C., and Prasad, M. (2013). Validation of an allele-specific marker associated with dehydration stress tolerance in a core set of foxtail millet accessions. Plant Breed. 132, 496-499. doi: 10.1111/j.1439-0523.2012. 01983.x

Lata, C., Sarita, J. H. A., Dixit, V., Sreenivasulu, N., and Parasad, M. (2011b). Differential antioxidative responses to dehydration-induced oxidative stress in core set of foxtail millet cultivars [Setaria italica (L.)]. Protoplasma 248, 817-828. doi: 10.1007/s00709-010-0257-y

Li, C., Yue, J., Wu, X., Xu, C., and Yu, J. (2014). ABA-responsive DRE binding protein gene from Setaria italica, SiARDP, the target gene of SiAREB, plays a critical role under drought stress. J. Exp. Bot. 65, 5415-5427. doi: 10.1093/jxb/ eru302

Li, P., and Brutnell, T. P. (2011). Setaria viridis and Setaria italica, model genetic systems for the panicoid grasses. J. Exp. Bot. 62, 3031-3037. doi: 10.1093/jxb/ err096

Li, W., Wang, Y., Okamoto, M., Crawford, N. M., Siddiqi, M. Y., and Glass, A. D. (2007). Dissection of the AtNRT2.1:AtNRT2.2 inducible high-affinity nitrate transporter gene cluster. Plant Physiol. 143, 425-433. doi: 10.1104/pp.106. 091223

Li, W. W., Chen, M., Zhong, L., Liu, J. M., Xu, Z. S., Li, L. C., et al. (2015). Overexpression of the autophagy-related gene SiATG8a from foxtail millet (Setaria italica L.) confers tolerance to both nitrogen starvation and drought stress in Arabidopsis. Biochem. Biophys. Res. Commun. 468, 800-806. doi: 10. 1016/j.bbrc.2015.11.035

Li, Z., Xu, C., Li, K., Yan, S., Qu, X., and Zhang, J. (2012). Phosphate starvation of maize inhibits lateral root formation and alters gene expression in the lateral root primordium zone. BMC Plant Biol. 12:89. doi: 10.1186/1471-2229-12-89

Liu, K. H., and Tsay, Y. F. (2003). Switching between the two action modes of the dual-affinity nitrate transporter CHL1 by phosphorylation. EMBO J. 22, 1005-1013. doi: 10.1093/emboj/cdg118

Liu, X., Tang, S., Jia, G., Schnable, J. C., Su, H., Tang, C., et al. (2016). The C-terminal motif of SiAGO1b is required for the regulation of growth, development and stress responses in foxtail millet (Setaria italica (L.) P. Beauv). J. Exp. Bot. 67, 3237-3249. doi: 10.1093/jxb/erw135

Loqué, D., and von Wirén, N. (2004). Regulatory levels for the transport of ammonium in plant roots. J. Exp. Bot. 55, 1293-1305. doi: 10.1093/jxb/erh147

Maeda, Y., Konishi, M., Kiba, T., Sakuraba, Y., Sawaki, N., Kurai, T., et al. (2018). A NIGT1-centred transcriptional cascade regulates nitrate signalling 
and incorporates phosphorus starvation signals in Arabidopsis. Nat. Commun. 9:1376. doi: 10.1038/s41467-018-03832-6

Marsch-Martinez, N., and de Folter, S. (2016). Hormonal control of thedevelopment of the gynoecium. Curr. Opin. Plant Biol. 29, 104-114. doi: 10.1016/j.pbi.2015.12.006

Marschner, H. (1995). Mineral Nutrition of Higher Plants. San Diego, CA: Academic Press.

Miller, A. J., and Cramer, M. D. (2004). Root nitrogen acquisition and assimilation. Plant Soil 27, 1-36. doi: 10.1007/s11104-004-0965-1

Miller, A. J., Shen, Q., and Xu, G. (2009). Freeways in the plant: transporters for N, P and S and their regulation. Curr. Opin. Plant Biol. 12, 284-290. doi: 10.1016/j.pbi.2009.04.010

Mishra, A. K., Puranik, S., Bahadur, R. P., and Prasad, M. (2012). The DNAbinding activity of an AP2 protein is involved in transcriptional regulation of a stressresponsive gene, SiWD40, in foxtail millet. Genomics 100, 252-263. doi: 10. 1016/j.ygeno.2012.06.012

Mittler, R. (2006). Abiotic stress, the field environment and stress combination. Trends Plant Sci. 11, 15-19. doi: 10.1016/j.tplants.2005.11.002

Mudge, S. R., Rae, A. L., Diatloff, E., and Smith, F. W. (2002). Expression analysis suggests novel roles for members of the Pht1 family of phosphate transporters in Arabidopsis. Plant J. 3, 341-353. doi: 10.1046/j.1365-313x.2002.01356.x

Mustilli, A. C., Merlot, S., Vavasseur, A., Fenzi, F., and Giraudat, J. (2002). Arabidopsis OST1 protein kinase mediates the regulation of stomatal aperture by abscisic acid and acts upstream of reactive oxygen species production. Plant Cell 14, 3089-3099. doi: 10.1105/tpc.007906

Muthamilarasan, M., Bonthala, V. S., Khandelwal, R., Jaishankar, J., Shweta, S., Nawaz, K., et al. (2015). Global analysis of WRKY transcription factor superfamily in Setaria identifies potential candidates involved in abiotic stress signaling. Front. Plant Sci. 6:910. doi: 10.3389/fpls.2015.00910

Muthamilarasan, M., Mangu, V. R., Zandkarimi, H., Prasad, M., and Baisakh, N. (2016). Structure, organization and evolution of ADP-ribosylation factors in rice and foxtail millet, and their expression in rice. Sci. Rep. 6:24008. doi: $10.1038 /$ srep 24008

Nacry, P., Bouguyon, E., and Gojon, A. (2013). Nitrogen acquisition by roots: physiological and developmental mechanisms ensuring plant adaptation to a fluctuating resource. Plant Soil 370, 1-29. doi: 10.1007/s11104-013-1645-9

Nadeem, F., Ahmad, Z., Wang, R., Han, J., Shen, Q., Chang, F., et al. (2018). Foxtail Millet [Setaria italica (L.) Beauv.] Grown under low nitrogen shows a smaller root system, enhanced biomass accumulation, and nitrate transporter expression. Front. Plant Sci. 9:205. doi: 10.3389/fpls.2018.00205

Narawongsanont, R., Kabinpong, S., Auiyawong, B., and Tantitadapitak, C. (2012). Cloning and characterization of AKR4C14, a rice Aldo-Keto Reductase, from Thai jasmine rice. Protein J. 31, 35-42. doi: 10.1007/s10930-011-9371-8

Neill, S. J., Desikan, R., Clarke, A., and Hancock, J. T. (2002). Nitric oxide is a novel component of abscisic acid signaling in stomatal guard cells. Plant Physiol. 128, 13-16. doi: 10.1104/pp.010707

Niu, Y. F., Chai, R. S., Jin, G. L., Wang, H., Tang, C. X., and Zhang, Y. S. (2013). Responses of root architecture development to low phosphorus availability: a review. Ann. Bot. 112, 391-408. doi: 10.1093/aob/mcs285

Nussaume, L., Kanno, S., Javot, H., Marin, E., Pochon, N., Ayadi, A., et al. (2011). Phosphate import in plants: focus on the PHT1 transporters. Front. Plant Sci. 2:83. doi: $10.3389 /$ fpls.2011.00083

Oberschall, A., Deak, M., Torok, K., Sass, L., Vass, I., Kovacs, I., et al. (2000). A novel aldose/aldehyde reductase protects transgenic plants against lipid peroxidation under chemical and drought stress. Plant J. 24, 437-446. doi: 10.1046/j.1365313x.2000.00885.x

Okamoto, M., Kumar, A., Li, W., Wang, Y., Siddiqi, M. Y., Crawford, N. M., et al. (2006). High-affinity nitrate transport in roots of Arabidopsis depends on expression of the NAR2-like gene AtNRT3.1. Plant Physiol. 140, 1036-1046. doi: $10.1104 /$ pp.105.074385

Orsel, M., Chopin, F., Leleu, O., Smith, S. J., Krapp, A., Daniel-Vedele, F., et al. (2006). Characterization of a two-component high-affinity nitrate uptake system in Arabidopsis: physiology and protein-protein interaction. Plant Physiol. 142, 1304-1317. doi: 10.1104/pp.106. 085209

Panigrahy, M., Rao, D. N., and Sarla, N. (2009). Molecular mechanisms in response to phosphate starvation in rice. Biotechnol. Adv. 27, 389-397. doi: 10.1016/j. biotechadv.2009.02.006
Péret, B., Clément, M., Nussaume, L., and Desnos, T. (2011). Root developmental adaptation to phosphate starvation: better safe than sorry. Trends Plant Sci. 16, 442-450. doi: 10.1016/j.tplants.2011.05.006

Pérez-Torres, C. A., López-Bucio, J., Cruz-Ramírez, A., Ibarra-Laclette, E., Dharmasiri, S., Estelle, M., et al. (2008). Phosphate availability alters lateral root development in Arabidopsis by modulating auxin sensitivity via a mechanism involving the TIR1 auxin receptor. Plant Cell 20, 3258-3272. doi: 10.1105/tpc. 108.058719

Poorter, H., Niklas, K. J., Reich, P. B., Oleksyn, J., Poot, P., and Mommer, L. (2012). Biomass allocation to leaves, stems and roots: meta-analyses of interspecific variation and environmental control. New Phytol. 193, 30-50. doi: 10.1111/j. 1469-8137.2011.03952.x

Postgate, J. (1998). Nitrogen Fixation, 3rd Edn. Cambridge: Cambridge University Press.

Puranik, S., Bahadur, R. P., Srivastava, P. S., and Prasad, M. (2011a). Molecular cloning and characterization of a membrane associated NAC family gene, SiNAC from foxtail millet [Setaria italica (L.) P. Beauv.]. Mol. Biotechnol. 49, 138-150. doi: 10.1007/s12033-011-9385-7

Puranik, S., Jha, S., Srivastava, P. S., Sreenivasulu, N., and Prasad, M. (2011b). Comparative transcriptome analysis of contrasting foxtail millet cultivars in response to short-term salinity stress. J. Plant Physiol. 168, 280-287. doi: 10. 1016/j.jplph.2010.07.005

Qi, X., Xie, S., Liu, Y., Yi, F., and Yu, J. (2013). Genome-wide annotation of genes and noncoding RNAs of foxtail millet in response to simulated drought stress by deep sequencing. Plant Mol. Biol. 83, 459-473. doi: 10.1007/s11103-013-0 104-6

Rae, A. L., Cybinski, D. H., Jarmey, J. M., and Smith, F. W. (2003). Characterization of two phosphate transporters from barley: evidence for diverse function and kinetic properties among members of the Pht1 family. Plant Mol. Biol. 53, 27-36. doi: 10.1023/B:PLAN.0000009259.75314.15

Raghotama, K. G. (1999). Phosphate acquisition. Annu. Rev. Plant Physiol. Plant Mol. Biol. 50, 665-693. doi: 10.1146/annurev.arplant.50.1.665

Rakshit, S., and Ganapathy, K. N. (2014). "Comparative genomics of cereal crops: status and future prospects," in Agricultural Bioinformatics, eds P. B. Kavi Kishor, R. Bandopadhyay, and P. Suravajhala, (New Delhi: Springer), 59-87. doi: 10.1007/978-81-322-1880-7_4

Rausch, C., and Bucher, M. (2002). Molecular mechanisms of phosphate transport in plants. Planta 216, 23-37. doi: 10.1007/s00425-002-0921-3

Regad, F., Bardet, C., Tremousaygue, D., Moisan, A., Lescure, B., and Axelos, M. (1993). cDNA cloning and expression of an Arabidopsis GTP-binding protein of the ARF family. FEBS Lett. 316, 133-136. doi: 10.1016/0014-5793(93)81201-a

Reich, P. B., Hobbie, S. E., Lee, T., Ellsworth, D. S., West, J. B., Tilman, D., et al. (2006). Nitrogen limitation constrains sustainability of ecosystem response to $\mathrm{CO}_{2}$. Nature 440, 922-925. doi: 10.1038/nature04486

Reymond, M., Svistoonoff, S., Loudet, O., Nussaume, L., and Desnos, T. (2006). Identification of QTL controlling root growth response to phosphate starvation in Arabidopsis thaliana. Plant Cell Environ. 29, 115-125. doi: 10.1111/j.13653040.2005.01405.x

Rose, T. J., Rose, M. T., Pariasca-Tanaka, J., Heuer, S., and Wissuwa, M. (2011). The frustration with utilization: why have improvements in internal phosphorus utilization efficiency in crops remained so elusive? Front. Plant Nutr. 2:73. doi: $10.3389 /$ fpls.2011.00073

Sabatini, S., Beis, D., Wolkenfelt, H., Murfett, J., Guilfoyle, T., Malamy, J., et al. (1999). An auxin-dependent distal organizer of pattern and polarity in the Arabidopsis root. Cell 99, 463-472. doi: 10.1016/s0092-8674(00) 81535-4

Sanchez, P. A., and Salinas, J. G. (1981). Low input technology for managing oxisol and ultisols in tropical America. Adv. Agron. 34, 279-406. doi: 10.1016/S00652113(08)60889-5

Schachtman, D. P., Reid, R. J., and Ayling, S. M. (1998). Phosphorus uptake by plants: from soil to cell. Plant Physiol. 116, 447-453. doi: 10.1104/pp.116.2.447

Schonbeck, M., and Morse, R. (2006). Cover Crops for All Seasons: Expanding the Cover Crop Tool Box for Organic Vegetable Producers. Virginia Association for Biological Farming Information Sheet. Available at: https://www.sare.org/ content/download/69536/985534/Cover_crops_for_all_seasons.pdf (accessed November 6, 2019).

Sheahan, C. M. (2014). Plant Guide for Foxtail Millet (Setaria italica). Cape May, NJ: USDA-Natural Resources Conservation Service. 
Shi, L., Shi, T., Broadley, M. R., White, P. J., Long, Y., Meng, J., et al. (2013). Highthroughput root phenotyping screens identify genetic loci associated with root architectural traits in Brassica napus under contrasting phosphate availabilities. Ann. Bot. 112, 381-389. doi: 10.1093/aob/mcs245

Shin, R., Berg, R. H., and Schachtman, D. P. (2005). Reactive oxygen species and root hairs in Arabidopsis root response to nitrogen, phosphorus and potassium deficiency. Plant Cell Physiol. 46, 1350-1357. doi: 10.1093/pcp/pci145

Shin, R., and Schachtman, D. P. (2004). Hydrogen peroxide mediates plant root cell response to nutrient deprivation. Proc. Natl. Acad. Sci. U.S.A. 101, 8827-8832. doi: 10.1073/pnas.0401707101

Skirycz, A., and Inze, D. (2010). More from less: plant growth under limited water. Curr. Opin. Biotechnol. 21, 197-203. doi: 10.1016/j.copbio.2010.03.002

Sofo, A., Scopa, A., Nuzzaci, M., and Vitti, A. (2015). Ascorbate peroxidase and catalase activities and their genetic regulation in plants subjected to drought and salinity stresses. Int. J. Mol. Sci. 16, 13561-13578. doi: 10.3390/ijms160613561

Sreenivasulu, N., Miranda, M., Prakash, H. S., Wobus, U., and Weschke, W. (2004). Transcriptome changes in foxtail millet genotypes at high salinity: identification and characterization of a PHGPX gene pecifically upregulated by $\mathrm{NaCl}$ in a salt-tolerant line. J. Plant Physiol. 161, 467-477. doi: 10.1078/0176-1617-01112

Stevens, C. J., Lind, E. M., Hautier, Y., Harpole, W. S., Borer, E. T., Hobbie, S., et al. (2015). Anthropogenic nitrogen deposition predicts local grassland primary production worldwide. Ecology 96, 1459-1465. doi: 10.1890/14-1902.1

Sudhakar, C., Veeranagamallaiah, G., Nareshkumar, A., Sudhakarbabu, O., Sivakumar, M., Pandurangaiah, M., et al. (2015). Polyamine metabolism influences antioxidant defense mechanism in foxtail millet (Setaria italica L.) cultivars with different salinity tolerance. Plant Cell Rep. 34, 141-156. doi: 10.1007/s00299-014-1695-3

Sun, J., Gibson, K. M., Kiirats, O., Okita, T. W., and Edwards, G. E. (2002). Interactions of nitrate and $\mathrm{CO}_{2}$ enrichment on growth, carbohydrates and rubisco in Arabidopsis starch mutants. Significance of starch and hexose. Plant Physiol. 130, 1573-1583. doi: 10.1104/pp.010058

Sutton, M. A., Oenema, O., Erisman, J. W., Leip, A., van Grinsven, H., and Winiwarter, W. (2011). Too much of a good thing. Nature 472, 159-161. doi: $10.1038 / 472159$ a

Svistoonoff, S., Creff, A., Reymond, M., Sigoillot-Claude, C., Ricaud, L., Blanchet, A., et al. (2007). Root tip contact with low-phosphate media reprograms plant root architecture. Nat. Genet. 39, 792-796. doi: 10.1038/ng2041

Syers, J., Johnston, A., and Curtin, D. (2008). Efficiency of Soil and Fertilizer Phosphorus Use: Reconciling Changing Concepts of Soil Phosphorus Behaviour With Agronomic Information. Rome: FAO.

Taub, D. R., and Wang, X. (2008). Why are nitrogen concentrations in plant tissues lower under elevated $\mathrm{CO} 2$ ? A critical examination of the hypotheses. J. Integr. Plant Biol. 50, 1365-1374. doi: 10.1111/j.1744-7909

Tegeder, M., and Masclaux-Daubresse, C. (2018). Source and sink mechanisms of nitrogen transport and use. New Phytol. 217, 35-53. doi: 10.1111/nph.14876

Thibaud, M. C., Arrighi, J. F., Bayle, V., Chiarenza, S., Creff, A., Bustos, R., et al. (2010). Dissection of local and systemic transcriptional responses to phosphate starvation in Arabidopsis. Plant J. 64, 775-789. doi: 10.1111/j.1365-313X.2010. 04375.x

Ticconi, C. A., Lucero, R. D., Sakhonwasee, S., Adamson, A. W., Creff, A., Nussaume, L., et al. (2009). ER-resident proteins PDR2 and LPR1 mediate the developmental response of root meristems to phosphate availability. Proc. Natl. Acad. Sci. U.S.A. 106, 14174-14179. doi: 10.1073/pnas.0901778106

Tilman, D., Reich, P. B., and Knops, J. M. (2006). Biodiversity and ecosystem stability in a decade-long grassland experiment. Nature 441, 629-632. doi: 10.1038/nature04742

Tsay, Y. F., Chiu, C. C., Tsai, C. B., Ho, C. H., and Hsu, P. K. (2007). Nitrate transporters and peptide transporters. FEBS Lett. 581, 2290-2300. doi: 10.1016/ j.febslet.2007.04.047

Tsay, Y. F., Schroeder, J. I., Feldmann, K. A., and Crawford, N. M. (1993). The herbicide sensitivity gene Chll of Arabidopsis encodes a nitrateinducible nitrate transporter. Cell 72, 705-713. doi: 10.1016/0092-8674(93) 90399-b

Turoczy, Z., Kis, P., Torok, K., Cserhati, M., Lendvai, A., Dudits, D., et al. (2011). Overproduction of a rice Aldo-Keto reductase increases oxidative and heat stress tolerance by malondialdehyde and methylglyoxal detoxification. Plant Mol. Biol. 75, 399-412. doi: 10.1007/s11103-0119735-7
Veeranagamallaiah, G., Chandraobulreddy, P., Jyothsnakumari, G., and Sudhakar, C. (2007). Glutamine synthetase expression and pyrroline-5-carboxylate reductase activity influence proline accumulation in two cultivars of foxtail millet (Setaria italica L.) with differential salt sensitivity. Environ. Exp. Bot. 60, 239-244. doi: 10.1016/j.envexpbot.2006.10.012

Veeranagamallaiah, G., Jyothsnakumari, G., Thippeswamy, M., Reddy, C. O. P., Surabhi, G. K., Sriranganayakulu, G., et al. (2008). Proteomic analysis of salt stress responses in foxtail millet (Setaria italica L. cv. Prasad) seedlings. Plant Sci. 175, 631-641. doi: 10.1016/j.plantsci.2008.06.017

Veeranagamallaiah, G., Ranganayakulu, G. S., Thippeswamy, M., Sivakumar, M., Reddy, E. K., Pandurangaiah, M., et al. (2009). Aldose reductase expression contributes in sorbitol accumulation and 4-hydroxynon-2-enal detoxification in two foxtail millet (Setaria italica L.) cultivars with different salt stress tolerance. Plant Growth Regul. 59, 137-143. doi: 10.1007/s10725-009-9396-6

Verwoert, I., Brown, A., Slabas, A. R., and Stuitje, A. R. (1995). A Zea mays GTPbinding protein of the ARF family complements an Escherichia coli mutant with a temperature-sensitive malonylcoenzyme A:acyl carrier protein transacylase. Plant Mol. Biol. 27, 629-633. doi: 10.1007/bf00019329

Vidal, E. A., and Gutiérrez, R. A. (2008). A systems view of nitrogen nutrient and metabolite responses in Arabidopsis. Curr. Opin. Plant Biol. 11, 521-529. doi: 10.1016/j.pbi.2008.07.003

Wang, M., Li, P., Li, C., Pan, Y., Jiang, X., Zhu, D., et al. (2014). SiLEA14, a novel atypical LEA protein, confers abiotic stress resistance in foxtail millet. $B M C$ Plant Biol. 14:290. doi: 10.1186/s12870-014-0290-7

Wang, M., Pan, Y., Li, C., Liu, C., Zhao, Q., Ao, G. M., et al. (2011). Culturing of immature inflorescences and Agrobacterium-mediated transformation of foxtail millet (Setaria italica). Afr. J. Biotechnol. 10, 16466-16479. doi: 10.5897/ ajb10.2330

Wang, W., Hu, B., Li, A., and Chu, C. (2019). NRT1.1s in plants: functions beyond nitrate transport. J. Exp. Bot. doi: 10.1093/jxb/erz554 [Epub ahead of print].

Wang, Y., Mi, G., Chen, F., and Zhang, F. (2003). Genotypic differences in nitrogen uptake by maize inbred lines its relation to root morphology. Acta Ecol. Sin. 23, 297-302.

Wang, Y., Tang, H., DeBarry, J. D., Tan, X., Li, J. P., Wang, X. Y., et al. (2012). MCScanX: a toolkit for detection and evolutionary analysis of gene synteny and collinearity. Nucleic Acids Res. 40:e49. doi: 10.1093/nar/gkr1293

Werdin-Pfisterer, N. R., Kielland, K., and Boone, R. D. (2012). Buried organic horizons represent amino acid reservoirs in boreal forest soils. Soil Biol. Biochem. 55, 122-131. doi: 10.1016/j.soilbio.2012.06.012

Wilkinson, S., and Davies, W. J. (2002). ABA-based chemical signalling: the coordination of responses to stress in plants. Plant Cell Environ. 25, 195-210. doi: 10.1046/j.0016-8025.2001.00824.x

Williamson, L. C., Ribrioux, S. P., Fitter, A. H., and Leyser, H. M. (2001). Phosphate availability regulates root system architecture in Arabidopsis. Plant Physiol. 126, 875-882. doi: 10.1104/pp.126.2.875

Wilmoth, J. C., Wang, S., Tiwari, S. B., Joshi, A. D., Hagen, G., Guilfoyle, T. J., et al. (2005). NPH4/ARF7 and ARF19 promote leaf expansion and auxin-induced lateral root formation. Plant J. 43, 118-130. doi: 10.1111/j.1365-313X.2005. 02432. $\mathrm{x}$

Wolters, H., and Jürgens, G. (2009). Survival of the flexible: hormonal growthcontrol and adaptation in plant development. Nat. Rev. 10, 305-317. doi: $10.1038 / \mathrm{nrg} 2558$

Xu, G., Fan, X., and Miller, A. J. (2012). Plant nitrogen assimilation and use efficiency. Ann. Rev. Plant Biol. 63, 153-182. doi: 10.1146/annurev-arplant042811-105532

Yadav, C. B., Muthamilarasan, M., Dangi, A., Shweta, S., and Prasad, M. (2016). Comprehensive analysis of SET domain gene family in foxtail millet identifies the putative role of SiSET14 in abiotic stress tolerance. Sci. Rep. 6:32621. doi: $10.1038 /$ srep32621

Yamaguchi, S. (2008). Gibberellin metabolism and its regulation. Ann. Rev. Plant Biol. 59, 225-251. doi: 10.1146/annurev.arplant.59.032607.092804

Yamaguchi-Shinozaki, K., and Shinozaki, K. (1994). A novel cis-acting element in an Arabidopsis gene is involved in responsiveness to drought, low-temperature, or high-salt stress. Plant Cell 6, 251-264. doi: 10.1105/tpc.6.2.251

Yamaguchi-Shinozaki, K., and Shinozaki, K. (2006). Transcriptional regulatory networks in cellular responses and tolerance to dehydration and cold stresses. Annu. Rev. Plant Biol. 57, 781-803. doi: 10.1146/annurev.arplant.57.032905. 105444 
Ye, Y., Yuan, J., Chang, X., Yang, M., Zhang, L., Lu, K., et al. (2015). The phosphate transporter gene OsPht $; 4$ is involved in phosphate homeostasis in rice. PLoS One 10:e0126186. doi: 10.1371/journal.pone.0126186

Yuan, J. C., Song, J. H., Ma, H. L., Song, X. Q., Wei, H. P., and Liu, Y. H. (2013). Ectopic expression a maize ADP-ribosylation factor gene in Arabidopsis, increase plant size and growth rate. J. Plant. Biochem. Biotechnol. 24, 161-166. doi: 10.1007/s13562-013-0248-0

Zhang, F., Sun, Y., Pei, W., Jain, A., Sun, R., Cao, Y., et al. (2015). Involvement of OsPht1;4 in phosphate acquisition and mobilization facilitates embryo development in rice. Plant J. 82, 556-569. doi: 10.1111/tpj.12804

Zhang, G., Liu, X., Quan, Z., Cheng, S., Xu, X., Pan, S., et al. (2012). Genome sequence of foxtail millet (Setaria italica) provides insights into grass evolution and biofuel potential. Nat. Biotechnol. 30, 549-554. doi: 10.1038/nbt.2195

Zhang, J. P., Liu, T. S., Zheng, J., Jin, Z., Zhu, Y., Guo, J. F., et al. (2007). Cloning and characterization of a putative 12 -oxophytodienoic acid reductase cDNA induced by osmotic stress in roots of foxtail millet. DNA Seq. 18, 138-144. doi: 10.1080/10425170601060764

Zhao, L., Zhao, Q., Ao, G., and Yu, J. (2009). The foxtail millet Si69 gene is a Wali7 (wheat aluminium-induced protein 7) homologue and may function in aluminium tolerance. Chin. Sci. Bullet. 54, 1697-1706. doi: 10.1007/s11434009-0238-8
Zheng, Z., Wang, Z., Wang, X., and Liu, D. (2019). Blue light-triggered chemical reactions underlie phosphate deficiency-induced inhibition of root elongation of Arabidopsis seedlings grown in petri dishes. Mol. Plant 12, 1515-1523. doi: 10.1016/j.molp.2019.08.001

Zhu, X. L., Zhang, L., Chen, Q., Wan, J., and Yang, G. F. (2006). Interactions of aryloxyphenoxypropionic acids with sensitive and resistant acetyl-coenzyme a carboxylase by homology modeling and molecular dynamic simulations. J. Chem. Inf. Model. 46, 1819-1826. doi: 10.1021/ci06 00307

Conflict of Interest: The authors declare that the research was conducted in the absence of any commercial or financial relationships that could be construed as a potential conflict of interest.

Copyright (c) 2020 Nadeem, Ahmad, Ul Hassan, Wang, Diao and Li. This is an open-access article distributed under the terms of the Creative Commons Attribution License (CC BY). The use, distribution or reproduction in other forums is permitted, provided the original author(s) and the copyright owner(s) are credited and that the original publication in this journal is cited, in accordance with accepted academic practice. No use, distribution or reproduction is permitted which does not comply with these terms. 